\title{
Assessing Everyday Peace Indicators (EPI) in Tandi and Padampur Areas in Chitwan, Nepal
}

\author{
Sushila Chatterjee Nepali, PhD \\ Visiting Faculty at Department of Conflict, \\ Peace and Development Studies, Tribhuvan University \\ Email: sushinep@gmail.com \\ Chiranjibi Bhandari \\ Assistant Professor at Department of Conflict, \\ Peace and Development Studies, Tribhuvan University \\ Email: cbhandari1986@gmail.com
}

\begin{abstract}
Everyday Peace Indicators (EPI) measures the community level indicators of peace and strategies developed to ensure long lasting peace not only in the level of individuals and community but towards achieving broader goal of the country. Realizing significance of grass root level indicators, in academic discourse and policy formulation, this article centered on the accepted wisdom of peace by wide ranges of people with their experiences, feelings and aspirations, which is summarized as everyday indicators. This core focus of this article is EPI, which is based on people's testimony collected in May 2017 in two communities of Chitwan district of Nepal. Summarizing the common aspirations of people, political stability, security, peace and access to basic needs are considered as common indicators of everyday peace among individuals participated in research process. Also, the freedom from fear, involvement in income generating activities and ownership of property in the name of women, adequate job opportunities and access to basic services; i.e. health, education, transportation and alcohol free environment in communities, religious and cultural freedom, harmony among the people in communities were identified as common indicators of peace.
\end{abstract}

Keywords: Peace, rural, urban, everyday peace indicator, security

\section{Introduction}

In general peace is freedom from war or hostilities; that condition of a nation or community in which it is not at war with another. Peace is not static. It is contextual; it has been viewed as absence of tension having the presence of justice or a respecting human rights, well being and freedom of individuals or a virtue and state of mind or absence of violence to attain social goals (King \& King, 2014; Abrams, 1995; Brussel, 1970; Fishel, 2008 and Galtung, 1969). Prior to the study of everyday peace indicators, it is important to be on familiar terms with that human society has been in conflict within, between and among individuals, groups, communities, nations, regions and peace building came along with conflict (Pro-Public \& Seed, 2016). At the global level, Global Peace Index (GPI) is an attempt to measure the relative position of nations' and regions' peacefulness. The index gauges global peace using three broad themes: the level of safety and security in society, the extent of domestic and international conflict and the degree of militarization. The five year GPI shows Nepal to be in $93^{\text {th }}$ position ranking 2.08 for 2017 and ranked 82 with 2.058 in 2013 (IEP, 2017). Aligning with the GPI, EPI measures the individual to community level indicators of peace and strategies developed to ensure long lasting peace not only in the community but towards achieving the goals of National Planning Commission in Nepal.

After a decade long conflict in Nepal, Ministry of Peace and Reconstruction at national level and local peace committees at the district level were established. The Ministry was established in April 2007, in the aftermath of the signing of the Comprehensive Peace Accord (CPA) between the Government of Nepal and the then Communist Party of Nepal -Maoist. It was envisaged that the Ministry would assume the work of the previous Peace Secretariat in supporting the technical aspects of the peace process while also taking on increased operational functions in implementing provisions of the CPA. However, majority of peacebuilding initiatives in Nepal never tried to deal with peace indicators but have concentrated more in the sector of reconstructing the damages happened during the conflict. As indicated by Pro-Public and Seed (2016) study report, National Planning Commission included in its 13th plan (2013-2016) a program to strengthen 'Infrastructures for Peace'. Ministry of Peace and Reconstruction (delivering citizen-state peace services); the local peace committees (delivering intercommunity peace services); the community mediation committees (delivering interpersonal peace services); and the dialogue facilitator pools (delivering intrapersonal peace services) are some institutions already in existence to support peace. 
In common, everyday peace serves important analytical purchase by turning the lens on to peace in a locality and the experiences of different people as they negotiate their everyday lives (Williams, 2015). It assesses and investigates alternative, bottom-up indicators of peace and how such bottom-up information can be meaningfully integrated into policy processes to develop participatory indicators of peace in the communities of the study areas in order to develop a more participatory form of measurement and evaluation of program work and interventions in respective communities. Despite the engagement and sincere efforts of large number of organizations in peace building work, it is commonly believed that 'many of the approaches to measuring peace favored by international organizations, INGOs and donor governments are deficient' (Mac Ginty and Richmond, 2013). How peace is socially and spatially understood at communities is important for peace building programs and also the universal indicators on peacebuilding have also been criticized for failing to capture the complexities of local political, cultural and historical context. Country-level indicators, by comparison, can be designed to take on board unique circumstances (Mack 2014). In order to explain this grounded approach to "everyday peace" the article centrally draws on different scalar narratives and practices of peace.

\section{Research Methodology}

The nature of this research is qualitative and based on primary research through case study. The research site is Chitwan district, which is one of the rapidly growing cities in Nepal with migrated people of mix communities; from hill and Terai. Also, Tandi Bazar is one of the business hubs and considered as one of the potential conflict hotspot, if there is misunderstanding scale up between Madheshi and Hill People or ex-combatants and community members. Two places; Belsi Village of Ratnanagar Municipality and Padampur village of Kalika Municipality were chosen as research sites. The sites were chosen based on indicator belonging to low economic status of people in this particular area. No matter if they are from urban or rural, $80 \%$ of the respondents had their livelihood based on agriculture and livestock production. For the purpose of the study Delphi method was used to find and analyze the peace indicators, which was qualitative method. The original Delphi method was designed in 1950 by Norman Dalkey to solve issues in the Rand Corporation in the US. The objective of his study was to identify and discuss reliable views from experts in the company. Linstone and Turoff (2002) define the Delphi technique as a method for structuring a group communication process in the way that the process is effective in allowing a group of individuals to deal with a complex problem. This method is mostly used for problem solving, planning and decision-analysis. Primary data were collected conducting 10 focus group discussions (FGD), in which around 80 individuals participated in discussion process, including men, women and youth. Altogether 10, FGD were conducted with urban male and female, rural women and men and youth, whereas five FGDs were conducted in Tandi area and other five were in Padampur area. As the Delphi method does use sampling methods, respondents were chosen among in the rural and urban setting though these areas now were municipality: Urban Male groups and Urban Female groups; Low economic status and conflict affected women and male groups and Mixed youth groups.

\section{Literature Review}

The definition of peace by Johan Galtung indicates two dimensions. The first dimension is a "violence" dimension, consistent with the notion of "negative peace". The second dimension of peace indicated by absence of violence and "harmony" dimension, which refers to the degree that individuals, families, groups, communities, or nations are engaged in mutually harmonious relationships (Galtung, 1996). Peace is happiness, justice, health and other human ideals something every person and culture claims to desire and venerate, but which few if any achieve at least on an enduring basis (Webel \& Galtung, 2007). Therefore, in common, peace can be defined as condition in which individuals, families, groups, communities, and/or nations don't experience violence and engage in mutually harmonious relationships. Rummel (1981) interpreted peace has always been among humanity's highest values, seen as concord, or harmony and tranquillity. It was viewed as peace of mind or serenity, especially in the Eastern philosophy. It is defined as a state of law or civil government, a state of justice or goodness, a balance or equilibrium of Powers. It can also be said that, seeing peace as absolute harmony, serenity, or quietude; that is, as opposed to any kind of conflict, antagonistic or otherwise. It means Rummel further looked at the dimensions of peace in 3 conceptual frames that is-conceptual level, social level and conceptual (met peace) dimension. Rummel (1981) defined peace as perhaps the most popular (Western) view is as an absence of disagreement, hostility, or war, a meaning found in the New Testament and possibly an original meaning of the Greek word for peace, Irene. Pacifists have adopted this interpretation, for to them all violence is bad. Similarly, religious beliefs often seek to identify and address the basic problems 
of human life, including the conflicts between, among, and within persons and societies. The definition of Peace also stresses that it is a lack of conflict and freedom from fear of violence between heterogeneous social groups.

Therefore, it can be said that peace being a pleasant word also refers to the peaceful society and the beautiful world. So far peace is commonly understood as the absence of war or violent hostility, peace often involves compromise, and therefore is initiated with thoughtful active listening and communication to enhance and create genuine mutual understanding. In general, peace is freedom from war and violence, in which conditions people can live and work together happily without disagreement. As a dimension of peace, it can be classified into two ways; internal and external peace. It is said that internal peace is a state of calm, serenity and tranquillity of mind that arise due to having no sufferings or mental disturbances such as worry, anxiety, greed, desire, hatred, ill-will ,delusion and/or other defilements. Internal peace is peace within oneself; it is derived from practicing or training of mind of an individual. Khemanando (1995) explains that external peace occurs in society, nations and the world; it is a normal state of society, countries and the world and it is a state of peaceful and happy co-existence of people as well as nature. External peace, in order to see it clearly, can be described in its negative and positive sense. As negative sense, it is defined as the absence of war, hostility, agitation, social disorder, disturbances, social injustice, social inequality, violence, violation of human rights, riot, terrorism, ecological imbalance, and in positive sense it is perceived as a state of social harmony, social justice, social equality, friendship or friendly relation, concord, public order and security, respect for human rights and ecological balance, etc. World Council of curriculum and instructions paper sub-classified peace into nine level; intra personal, inter-personal, intra-group, inter-group, intra racial, inter-racial, intra-national, and international and world peace (Prachoomsuk, 1983).

Historically peace efforts have been documented from the ancient ages to current peace efforts by several authors indicating how welfare approaches, making justice and addressing human rights supported peace building and movements. As per the international peace movement history, the documentation mentions that the peace building to peace movements, several peace conferences took place like since the beginning of 1800's international conventions discussed peacekeeping and the first World Peace Conference met in London in 1843 and simultaneously Peace conferences met in many places: Brussels, Belgium, in 1848; Paris in 1849; and Frankfurt, Germany, in 1850 and in The Hague in the Netherlands in 1899 and 1907. Overall the concept of peace so far have been studies in depth and widely indicating varieties of concepts and perspectives on peace such as concept of human rights for peace, concept of justice for peace, concept of non-violence for peace, concept of peace education, concept of peace culture, concept of peace gender, concept of peace media, and concept of peace environment are presented to understand those concepts that peace is related to and those fields that peace is studied in. Everyday Peace Indicator here also tried to look into the conceptual to social level peace that strengthens the social cohesion, address the environmental justice and bringing happiness to individual to a society at last. Thus analyzing these peace indicators it can be observed that peace can be taken up as a construct means that "peace" serves a stepping-stone role in theory.

\section{Findings}

\section{Rural Indicators}

This section briefly summarizes how local actors actively negotiate and (re)produce peace as policy, narrative, practice and strategy within different urban and rural setting across different scales. The findings indicate that first the women may need movement of freedom, income generation and land ownership in their name. Besides that rural areas not having good education and job employment has been their worries and were found to be concerned about their kids future. Having access to services like health, education and alcohol free environment are some major indicators that have affected their daily life. All these indicators as said by them can be achieved if the political stability is there within the nation and good leaders in their community and not have discrimination among poor and rich classes. People expressed that to be free from hunger and availability of food throughout the year, adequate health facilities, involvement of women in income generation activities, no discrimination in communities, peaceful environment in academic institutions, free from drug consumption, women's participation in decision making level, absence of disputes in family affairs as well as quality education were considered as major determinants of peace by respondents. In most of the rural areas majority of the respondents do not have sufficient land that they can produce to feed their family and not having proper job makes their life worse off. Therefore having land is not sufficient they should be provided with good agriculture 
technologies which are gendered friendly. Regarding the health facilities, study areas don't have access to health centers and they have to travel a long distance when people are sick. Majority of the poor cannot afford to pay medical bills and they sometime be in debt, therefore health services has been their major concern for being in peace. Having income generation activities for women especially has been one of the key peace indicator, indicating that if women have some cash in hand they do not need to ask their husband and they can participate in cooperatives where they benefit to take loans and support their family in need. Income generation activities also make the women empowered and they think they can gain respect in the society as well. Family disputes were reported in the society from property rights issues and if they are resolved than peace can prevail in the society and even domestic violence reduced. It is believed that when students enter colleges they get into bad habits and after education they cannot find jobs they get into drugs and alcohol. Having good education and being educated is a peace indicator meaning if the society is educated then the discriminations are reduced and even the mothers can be of help to their children. Cultural and religious sites are the binding factors of social cohesion, but after the 10 year long conflict people believes that people are falling apart and peace can be attained when you go to the temples and be part of the cultural events.

\section{Urban Indicators}

Though the indicators were developed from two different sites of the urban areas and youth concern, the indicators of peace indicated having good governance, youth having good education and arms free to reduce violence in the society to areas having employment opportunity. The women especially mentioned having good education centers and temples where they could share their grief and be in peace. The Padampur site being a resettled area of ex-combatants and other migrated people, the concern of the community for peace is having their land ownership in their name and health services in the area provided by the government. When there is lack of job employment the rate of men and youth migrating is also high, which have increased tension among women thinking and hoping that their families are safe outside. When migrating people reside together, sense of trust is also low and needs to be built for strong social cohesion. The urban poor and middle class still feel discriminated not having equal opportunity in trainings and not able to enhance their skills for livelihood. If these trainings were provided then especially the women would have an opportunity do things on their own and men instead of drinking and gambling could work and divert their mind. For example in Padampur and Belsi women were finding peace being involved in thread weaving, sewing and tailoring or maize farming. The urban parents felt at peace when their kids are not into drugs and going to schools regularly. One critical issues of peace indicator were to have good services and infrastructure for drinking water, drainage and irrigation facilities for their daily livelihood compliances.

\section{Analysis}

The information discussed in the finding section clearly shows that peace and the indicators of peace are mostly influenced by the level of one's satisfaction. This level of satisfaction is not individual but covers the family and sometimes the extended one. Mostly discussed themes by participants are connected to structural factors related to violence and peace. In their view, violence is not only direct aggression to human beings, but it includes other kinds of factors that damage people, such as corruption or lack of opportunities inequality and tension in the society. For the everyday peace all the respondents felt that the environment and surrounding are also the major determinants of peace. Homes, movie hall, park, meditating space in community as well as touristic places outside the community are considered as determinant of peace. Also, homogenous society (people with similarities in nearby areas) is more peaceful in some context and heterogeneous in other. Usually if discrimination happens in the villages and in nation with respect to benefit sharing and access to services conflict arises and that needs to removed ensuring fair and equitable sharing of benefits and have access to services. Women were still not feeling empowered and not making their own decisions were some cases mentioned when they do not feel at peace. For example, if a woman was able to decide some of the stuffs without taking the permission from her husband, it really makes her happy and leads to peaceful situation. There have been cases reported that when the children fought the parents not talking to each other for a year not knowing these minor cases destroying the peace in the community.

"A case reported by women, from Tharu community, saying initially the women thought that there was no happiness when they were not formed in a group nor have their own saving and credit program that was initiated by Heifer International. When women joined all the men were angry and when the project staff or men visited in their communities, men used to say there your kings have arrived and now you go and worship them than do the house work, which created violence in the house. But later on the 
project taught the men of social cohesion and 7 Principles and ethics then slowly men were able to understand and today no violence and women have easy access to loan without collaterals".

As per the urban responses, respondents said that the world is founded in two things: greed and love - for this people will do - both peaceful and violent activities. Therefore, peace was not purely achieved it is relative and contextual. It was also observed from the Padampur area where more migrants were settled, they think that the area being the land of migrant people - which does not create strong bonds among the people in this locality. In some context, peace was interpreted as the condition of being all the family members at home. However it was just opposite when they would be in the group of unemployed crowd. Social cohesion happens where there is a give and take relationship in the society, Nepal believes a lot in barter system but diminishing, which maintained a trust and festival and social gathering like concerts and health camps and other social functions; peace events has been a medium for building peace and harmony. For example, in case of migrant people after resettled they felt that previously they were in their own place of origin - where as transportation from the place of origin to market areas were problem. In addition, lack of education facilities and health services were other problems. However, in terms of maintaining social cohesion and ensuring social solidarity in the time of crisis was good. The situation is different in new settled area. People are living in cluster - which is considered as slum settlement - only a tap, access to resources is problematic. Finding showed that locality also matters in the happiness of the people. Community surrounding also make significant changes in the life of the people. Discrimination prevails in various societies and cultures which is a rooted social and cultural norms such as Dalit (the untouchable groups) have to wash their own dishes and still not allowed to enter the Brahmin and Chhetri houses. Once they are migrants they have restriction on use of resources i.e. community forest, water resources, and other resources as well making them more vulnerable.

\section{Conclusion}

Reviewing the information gathered in different rounds, participants arrived at certain understanding that peace is possible, but only if structural conditions are adequately addressed. Investment in education, promoting economic growth, reducing inequalities, and fostering opportunities, are other factors explicitly shared by participants throughout the study. The need for building links, active participation, and promoting peace from the grassroots, were some of the repeated patterns during the focus group discussion. The fact that these themes reached saturation suggests that policymakers should pay attention to them. The key messages from everyday peace indicators from rural perspectives are as follows:

- Everyday peace is a requirement in the community for social cohesion

- Everyday peace is among the political parties could make country peace

- Everyday peace could supporting in creating tolerance, freedom of movement, communication and sharing of information

- Everyday peace can come when all the citizens are socio economically strong and equally educated.

- Everyday peace means reduction in discrimination among caste and class in the society.

Whereas, the key messages from everyday peace indicators from urban perspectives are summarized as:

- Everyday peace is a prerequisite for good governance

- Everyday peace is having good health, education and jobs and access to services and benefits equally by all the citizens

- Everyday peace in the community means having men not gambling and drinking alcohol and reduction in domestic violence

- Everyday peace is conducive when all the political parties are in less conflict and sense of trust is built

\section{References}

Abrams, I. (1995). The Words of Peace: Selections from the speeches of the winners of the Noble Peace Prize. New York: New Market Press.

Brussell, E.E. (1970). Dictionary of Quotable Definitions. Englewood Cliffs, NJ: Prentice-Hall.

Dalkey, N. (1970). The Delphi Method, IV: Effect of Percentile feedback and Feed-in of relevant facts. Santa Monica, CA: Rand.

Fishel, R. (2008). Peace in Our Hearts, Peace in the World: Meditations of Hope and Healing. New York: Sterling Publishing. 
Galtung, J. (1969). Violence, Peace, and Peace Research. Journal of Peace Research, 6(3), 167191. https://doi.org/10.1177/002234336900600301

Galtung, J. (1996). Peace by Peaceful Means: Peace and Conflict Development and Civilization. Norway: Sage Publications.

IEP report, (2017). Global Peace Index, 2017: Measuring Peace in a Complex World. Sydney: The Institute for Economics and Peace.

Khemanando, Ven. B. (1995). Buddhism and Peace. Calcutta: Lazo Print.

King, M. L. \& King, C.S. (2014). The Words of Martin Luther King, Jr. New York, NY: William Morrow, an imprint of Harper Collins.

Linstone, H. A. \& Murray T., (2002). The Delphi Method: Technique and Application Retrieved from https://web.njit.edu/ turoff/pubs/delphibook/delphibook.pdf

Mac G. R. \& Richmond, O. P. (2013) The Local Turn in Peace Building: a critical agenda for peace. Third World Quarterly, 34:5, 763-783, DOI: 10.1080/01436597.2013.800750

Mack, A. (2014). Measuring peacebuilding performance: why we need a "data revolution". Retrieved from http://www.cr.org/sites/default/files/Accord25_MeasuringPeacebuildingPerformance.pdf

Prachoomsuk, A. A. (1983), Peace Research, International Association of Educators for World Peace. World Peace Council: Bangkok, pp. 4-5.

Pro-Public and SEED (2016). Predictors of Peace and Violence in Nepal: An empirical study of peace needs and peace services. Kathmandu: Forum for Protection of Public Interest (Pro Public).

Rummel, R. J. (1981). Understanding conflict and war. Vol. (5). The Just Peace, Beverly Hills: Sage Publications.

Webel, C., \& Galtung, J (2007). Handbook of Peace and Conflict Studies. New York: Routledge: Taylor and Francis Group.

Williams, P. (2015). Everyday Peace?: Politics, Citizenship and Muslim Lives in India. Wiley Online Library. 